\title{
KESANTUNAN DIREKTIF GURU BAHASA INDONESIA DALAM PROSES BELAJAR-MENGAJAR DI SMP ANGGREK BANJARMASIN
}

\author{
Haswinda Harpriyanti ${ }^{1}$
}

\section{Program Studi Pendidikan Bahasa dan Sastra Indonesia STKIP PGRI Banjarmasin haswinda.h@stkipbjm.ac.id (085251428080)}

\begin{abstract}
ABSTRAK
Kesantunan sangat penting dalam sebuah komunikasi dengan adanya kesantunan berbahasa akan menimbulkan keharmonisan dalam berkomunikasi, terlebih dalam tindak direktif, khususnya dalam proses belajar-mengajar. Kalimat direktif digunakan untuk menyatakan sebuah perintah. Dalam interaksi belajarmengajar di sekolah tuturan direktif lebih dominan digunakan oleh seorang guru karena di dalam proses belajar-mengajar guru lebih berkuasa dari pada siswanya. Metode yang digunakan dalam penelitian ini adalah metode deskriptif. Analisis data dilakukan dengan cara pengklasifikasian data, penafsiran data, dan pendeskripsian hasil tafsiran. Dari hasil penelitian ini dapat disimpulkan bahwa tindak tutur direktif dalam proses belajar-mengajar terbagi menjadi (a) permintaan (requestives), yang mencakup meminta, mengajak, memohon, mendorong, menekan; (b) pertanyaan (questions), yang mencakup bertanya, menginterogasi; (c) persyaratan (requirements), yang mencakup menuntut, mengarahkan, mengatur, mengintruksikan; (d) larangan (prohibitions), yang mencakup melarang dan membatasi; (e) persilaan (permisives), yang mencakup pemberian izin, membolehkan, mengabulkan, memberi wewenag; (f) nasihat (advisories), yang mencakup menasihati, memperingatkan, menyarankan.
\end{abstract}

Kata kunci : Kesantunan, Direktif, belajar-mengajar

\section{PENDAHULUAN}

\section{A. Latar Belakang}

Bahasa merupakan satu wujud yang tidak bisa dipisahkan dari kehidupan manusia, sehingga dapat dikatakan bahwa bahasa itu adalah milik manusia yang telah menyatu dengan pemiliknya. Sebagai salah satu milik dari manusia, bahasa selalu muncul dalam segala aspek dan kegiatan manusia. Tidak ada satu pun kegiatan manusia yang tidak disertai dengan kehadiran bahasa. Rafiek (2007: 49) menyatakan bahasa adalah salah satu ciri yang paling khas manusiawi yang membedakannya dari makhluk-makhluk lain. Bahasa dapat dikaji dari beberapa sudut dan memberikan pengertian khusus pada unsur-unsur bahasa yang berbedabeda dan pada hubungan-hubungan (struktur) yang membeda-bedakan pula.

Dalam komunikasi tidak hanya menuntut penuturnya mempunyai penguasaan atas sistem bunyi dan bahasa, tetapi juga penguasaan atas kaidah sosial bahasa seperti kesantunan dalam bahasa. Lakoff dalam Chaer (2010: 46) 
mengatakan jika tuturan kita ingin terdengar santun ditelinga pendengar atau lawan tutur kita, ada tiga buah akidah yang harus dipatuhi. Ketiga buah kaidah kesantunan itu adalah formalitas (formality), ketidaktegasan (hesitancy), dan persamaan atau kesekawanan (equality or camaraderie). Ketiga kaidah itu apabila dijabarkan, maka yang pertama formalitas, berarti jangan memaksa atau angkuh (aloof); yang kedua, ketidaktegasan berarti buatlah sedemikian rupa sehingga lawan tutur dapat menentukan pilihan (option) dan yang ketiga persamaan atau kesekawanan, berarti bertindaklah seolah-olah Anda dan lawn tutur Anda menjadi sama.

Dari teori di atas dapat disimpulkan sebuah tuturan dikatakan santun apabila tuturan tersebut tidak terdengar memaksa atau angkuh, tuturan itu memberi pilihan kepada lawan tutur, dan lawan tutur merasa tenang. Kesantunan tidak hanya digunakan dalam menyatakan informasi, perjanjian, keputusan, penjelasan, menyatakan selamat, meminta pengakuan, pendapat, dan keterangan tepai juga digunakan dalam fungsi direktif. Kesantunan sebagai suatu konsep yang tegas, seperti gagasan 'tingkah laku sosial yang sopan, atau etiket, terdapat dalam budaya.

Dalam hal ini Chaer (2010: 6) mengemukakan bahwa kesantunan berbahasa lebih berkenaan dengan substansi bahasanya, maka kesantunan bahasa lebih berkenaan dengan perilaku atau tingkah laku di dalam bertutur. Tuturan tidak hanya berfungsi untuk mengatakan atau menginformasikan sesuatu, tetapi dapat dipergunakan untuk melakukan sesuatu. Tuturan itu dapat diwujudkan oleh seorang penutur melalui tindak lokusi, tidak ilokusi, dan tindak perlokusi.

Selanjutnya, Searle (dalam Leech, 1993: 164-165) mengklasifikasikan tindak tutur ilokusi menjadi lima kriteria yakni, asertif, komisif, ekspresif, deklarasi, dan direktif. Direktif bertujuan untuk menghasilkan efek berupa tindakan yang dilakukan oleh mitra tutur, misalnya, memesan, memerintah, memohon, menuntut, dan memberi nasihat. Fungsi tuturan direktif berorientasi pada penerima pesan. Dalam hal ini, bahasa dapat digunakan untuk mempengaruhi orang lain, baik emosi, perasaan, maupun tingkah laku.

Pemakainan kalimat direktif dapat digunakan di mana pun dan kapan pun tidak terkecuali di lingkungan pendidikan atau sekolah. Bahkan di lembaga formal inilah yang semestinya menjadi barometer pemakaian bahasa secara santun. Hubungan antara warga sekolah wajib menjaga kesantunan berbahasa dalam segala bentuk komunikasi khususnya dalam proses belajar-mengajar di sekolah tidak hanya antara siswa tetapi juga antar guru dengan siswanya, karena segala situasi dalam proses belajar-mengajar akan lebih efektif jika seorang guru mampu menggunakan bahasa dengan santun khusunya dalam fungsi direktifnya.

\section{B. Tujuan Penelitian}

Tujuan penelitian kesantunan direktif guru bahasa Indonesia dalam proses belajar-mengajar di SMP Anggrek Banjarmasin adalah untuk mendeskripsikan wujud kesantunan dan fungsi kesantunan direktif guru bahasa Indonesia dalam proses belajar-mengajar di SMP Anggrek Banjarmasin. 


\section{METODE PENELITIAN}

\section{A. Pendekatan dan Metode Penelitian}

Metode yang digunakan dalam penelitian ini adalah metode deskriptif dengan pendekatan kualitatif. Metode deskriptif adalah metode yang berusaha menggambarkan sesuatu yang terjadi dengan apa apanya. Pendekatan yang digunakan terhadap kesantunan direktif guru bahasa Indonesia di SMP Anggrek Banjarmasin adalah pendekatan kualitatif. Kualitatif adalah pendekatan yang diharapkan mampu menghasilkan suatu uaraian mendalam tentang ucapan, tulisan, atau perilaku yang diamati dari suatu individu, kelompok, masyarakat, dan suatu organisasi tertentu dalam suatu setting konteks tertentu yang dikaji dari sudut pandang yang utuh, komprehensif, dan holistic (Bogdan dan Taylor, dalam Basrowi dan Suwandi, 2008: 22-23).

\section{B. Sumber Data}

Sumber data dalam penelitian ini adalah orang yang menuturkan khususnya guru bahasa Indonesia yang sedang melaksanakan kegiatan proses belajar-mengajar di kelas. Tuturan yang diucapkan oleh guru tersebut merupakan salah satu data utama yang menjadi sumber data dalam penelitian ini.

\section{Teknik Pengumpulan Data}

Pengumpulan data dilakukan dengan teknik penyimakan penggunaan bahasa. Pada teknik ini memiliki teknik dasar yang berwujud teknik sadap. Teknik sadap di sebut sebagai teknik dasar dalam metode simak karena pada hakikatnya penyimakan diwujudkan dengan penyadapan. Dalam arti, peneliti dalam upaya mendapatkan data dilakukan dengan menyadap pengguanaan bahasa seseorang atau beberapa orang yang menjadi informan. (Mahsun, 2005: 92).

\section{Teknik Analisis Data}

Setelah data dikumpulkan dari berbagai sumber, selanjutnya dilakukan analisis data yang dalam penelitian ini berupa tuturan yang terdapat pada rekaman proses belajar-mengajar di kelas khusunya di SMP Anggrek Banjarmasin. Untuk menganalisis data penelitian ini dilakukan dengan teknik pengklasifikasian data, penafsiran data, dan pendeskripsian hasil tafsiran.

Penafsiran dilakukan setelah data dikelompokkan. Penafsiran dilakukan dengan cara menafsirkan makna yang terdapat pada tuturan yang dituturkan oleh guru bahasa Indonesia pada saat proses belajar-mengajar di kelas. Dengan memaksukkan teori kesantunan dan teori pragmatik pada bagian direktifnya. Setelah makna yang terdapat dirumuskan, tahap selanjutnya yaitu pendeskripsian makna tersebut dalam bentuk kata-kata. Untuk memudahkan pengklasifikasian dan penyajian hasil penelitian, peneliti menggunakan kode-kode berikut: Guru (G), Siswa (S).

\section{HASIL PENELITIAN DAN PEMBAHASAN}

\section{A. Wujud Kesantunan Direktif Guru Bahasa Indonesia dalam Proses Belajar-Mengajar di SMP Anggrek Banjarmasin}

Bahasa yang digunakan guru bahasa Indonesia pada saat proses belajarmengajar berlangsung di SMP Anggrek Banjarmasin banyak terdapat wujud kesantunan direktifnya yang dapat terbagi menjadi beberapa bagian, yakni (a) 
permintaan (requestives), yang mencakup meminta, mengajak, memohon, mendorong, menekan; (b) pertanyaan (questions), yang mencakup bertanya, berinkuiri, menginterogasi; (c) persyaratan (requirements), yang mencakup menuntut, mengarahkan, mengatur, mengintruksikan; (d) larangan (prohibitions), yang mencakup melarang dan membatasi; (e) persilaan (permisives), yang mencakup pemberian izin, membolehkan, mengabulkan, memberi wewenag; (f) nasihat (advisories), yang mencakup menasihati, memperingatkan, menyarankan.

\section{Wujud Kesantunan Direktif Permintaan (requestives)}

Penarapan wujud kesantunan direktif permintaan yang mencakup meminta, mengajak, memohon, mendorong, menekan dalam proses belajarmengajar dapat dilihat seperti.
[1] G : "Baiklah, kalau begitu sebelum kita memulai pelajaran hari ini. Mari kita berdoa terlebih dahulu." S :"'Iya Bu."
Konteks: (Tuturan di atas adalah tuturan antara guru dan siswa sebelum memulai pelajaran).

Dalam tuturan [1] terlihat bahwa [G] telah menerapkan wujud kesantunan direktif yang termasuk dalam kategori wujud kesantunan direktif permintaan yang berupa ajakan. Dapat di lihat dari tuturan yang di tuturkan oleh guru "Baiklah, kalau begitu sebelum kita memulai pelajaran hari ini. Mari kita berdoa terlebih dahulu." Kata baiklah dan mari dalam tuturan itu merupakan penanda kesantunan karena dengan adanya kata tersebut tuturan terasa menjadi lebih santun. Tuturan di atas sudah termasuk dalam wujud direktif permintaan dengan ditandai adanya kata ajakan mari.

[2] S :'Bagiannya ni pandir tarus." \{siswa bersuara ketika guru sedang menjelaskan\}.

("Mereka ini bicara terus")

G : :Nah, kerjakan tugas ja gen lah, tugasnya ada di halaman 27 di situ kalian tinggal menentukan haja lagi."

("Nah, kerjakan tugas saja ya, tugasnya ada di halaman 27 di situ kalian tinggal menentukan haja lagi.")

S1 :"Aduh, tugas lagi am."

(Aduh, tugas lagi deh.")

S2 :"Iya Bu. Dikerjakan di buku latihan kah Bu?"

G :"'Iya."

Konteks: (Tuturan di atas adalah tuturan antara guru dan siswa pada saat proses belajar-mengajar berlangsung, yang mana tuturan itu meminta siswa untuk mengerjakan tugas pada buku LKS yang telah tersedia dikarenakan siswa yang selalu rebut ketika gurunya berusaha menjelaskan materi pelajaran).

Dalam tuturan [2] terlihat bahwa [G] telah menerapkan wujud kesantunan direktif yang termasuk dalam kategori wujud kesantunan direktif permintaan yang berupa ajakan. Dapat di lihat dari tuturan yang di tuturkan guru "Nah, kerjakan tugas ja gen lah, tugasnya ada di halaman 
27 di situ kalian tinggal menentukan haja lagi.” Kata ja gen lah dalam tuturan itu yang memiliki arti saja ya merupakan penanda kesantunan karena dengan adanya kata tersebut tuturan terasa menjadi lebih santun, sehingga walaupun ada siswa yang mengeluhkan dengan adanya pemberian tugas tetapi masih banyak siswa yang menuruti permintaan guru untuk mengerjakan tugas tersebut. Tuturan [2] tersebut sudah termasuk dalam wujud direktif permintaan ditandai dengan penggunaan kata kerjakan tugas ja gen lah (kerjakan tugas saja ya) itu sudah dapat menunjukan suatu permintaan yang jelas dari guru kepada siswa.

\section{Wujud Kesantunan Direktif Pertanyaan (questions)}

Penarapan wujud kesantunan direktif pertanyaan yang mencakup bertanya, menginterogasi dalam proses belajar-mengajar dapat dilihat seperti.

[6] G : "Baiklah Abdurrahman. Apa itu pengumuman?"

S :"Pengumuman terbagi dua."

Konteks: (Tuturan di atas adalah tuturan antara guru kepada salah seorang siswa yang bernama Abdurrahman yang menanyakan tentang materi pelajaran yang sedang dipelajari pada hari itu).

Dalam tuturan [6] terlihat bahwa [Guru] telah menerapkan wujud kesantunan direktif yang termasuk dalam kategori wujud kesantunan direktif pertanyaan yang berupa bertanya. Dapat di lihat dari tuturan yang di tuturkan guru "Baiklah Abdurrahman. Apa itu pengumuman?" Kata baiklah pada tuturan di atas merupakan penanda kesantunan yang membuat tuturan di atas terasa lebih santun ketika dituturkan dan dengan disertainya penyebutan nama siswa yakni Abdurrahman hal tersebut juga mempengaruhi tuturan yang dituturkan tentunya akan menjadi lebih santun. Pada tuturan [6] dikatakan wujud direktif pertanyaan karena ditandai dengan adanya kata tanya berupa apa sehingga tuturan tersebut membentuk tuturan pertanyaan yang tentunya menuntut sebuah jawaban dari lawan tuturnya.

\section{Wujud Kesantunan Direktif Persyaratan (requirements)}

Penarapan wujud kesantunan direktif persyaratan yang mencakup menuntut, mengarahkan, mengatur, mengintruksikan, mengomando, mendikte dalam proses belajar-mengajar dapat dilihat seperti.

[14] G : "Tuliskan dulu nama, kelas di lembar jawaban kalian! Kalau ibu menulis di sini melihat lah ?"

S : "Silau."

Konteks: (Tuturan di atas adalah tuturan guru yang ditujukan kepada siswa-siswanya ketika ingin memulai ulangan harian).

Pada tuturan [14] [Guru] menunjukan wujud kesantunan direktif persyaratan. Dapat di lihat dari tuturannya "Tuliskan dulu nama, kelas di lembar jawaban Kalian! Kalau ibu menulis di sini melihat lah?" di tandai dengan kata dulu yang menunjukan syarat sebelum menuliskan soal ulangan harian siswa di minta untuk menuliskan nama dan kelas di lembar jawabannya masing-masing. Selain itu penggunan kata dulu juga dapat 
dikatakan sebagai penanda kesantunan pada tuturan [14] [Guru] tersebut karena dengan adanya kata dulu tuturan tersebut terdengar lebih bernilai santun.

\section{[15] S : "Badiaman ei." \\ ("Tolong diam semua") \\ G : "Tolong perhatikan ke depan!"}

Konteks: (Tuturan di atas adalah tuturan guru yang ditujukan kepada semua siswanya agar bisa memperhatikan ke depan untuk mendengarkan penjelasan yang akan disampaikan).

Pada tuturan [15] [Guru] menunjukan wujud kesantunan diraktif persyaratan yang berupa mengomando dapat di lihat pada tuturan "Tolong perhatikan ke depan!" penanda kesantunannya ditandai dengan adanya kata tolong dan dapat dikatakan sebagai persyaratan kategori mengomando karena dalam tuturan tersebut di tuturkan oleh [Guru] dengan tegas yang meminta semua siswanya untuk memperhatikan ke depan.

\section{Wujud Kesantunan Direktif Larangan (prohibitions)}

Penarapan wujud kesantunan direktif persyaratan yang mencakup melarang dan membatasi dalam proses belajar-mengajar dapat dilihat seperti.

[18] G : : "Hai, coba kata bungul jangan diucapkan. Belajar bahasa Indonesia kata yang baik digunakan. Kata yang tidak baik jangan dikeluarkan."

Konteks: (Tuturan [18] adalah sebuah tuturan yang ditutrkan oleh guru kepada siswanya yang ketika saat kegiatan belajar-mengajar berlangsung mengucapkan kata yang tidak sopan).

Pada tuturan [18] yang dituturkan oleh [Guru] merupakan tuturan yang termasuk dalam wujud larangan dapat di lihat dari modalitas yang melekat pada tuturan tersebut yaitu kata jangan yang berarti melarang. Sehingga tuturan [18] tersebut sudah jelas termasuk dalam wujud direktif larangan.

\section{Wujud Kesantunan Direktif Persilaan (permisives)}

Penarapan wujud kesantunan direktif persilaan yang mencakup memberi izin, mengabulkan dan member wewenang.

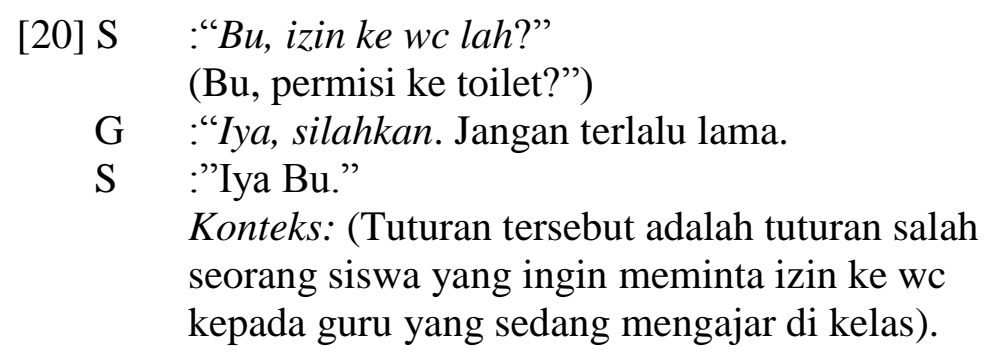

Pada tuturan [20] [Guru] menunjukan wujud kesantunan diraktif persilaan yang berupa memberikan izin dapat di lihat pada tuturan "Iya, silahkan. Jangan terlalu lama." Pada tuturan tersebut terdapat modalitas yang melekat yaitu penggunaan kata silahkan yang berarti mengizinkan siswanya untuk pergi ke toilet, sehingga tuturan [20] dapat dikategorikan ke dalam wujud kesantunan direktif persilaan. 


\section{Wujud Kesantunan Direktif Nasihat (advisories)}

Penarapan wujud kesantunan direktif nasihat yang mencakup menasihati, memperingatkan, mengusulkan, membimbing, dan menyarankan.
[22] G : "Yang menjawab lain ada? Jawabannya D. Nomor 25 jawabannya C. Nah, contoh-contoh soal yang seperti ini tolong kamu pahami betul. Perhatikan pertanyaannya, dipahami dulu baru memilih jawabannya. Nomor 26 jawabannya?"
$\mathrm{S} \quad$ : "B."
G : "Ya benar B, nomor 27?"
Konteks: (Tuturan [22] dituturkan oleh guru kepada siswa-siwanya ketika sedang membahas contoh- contoh soal ujian semester).

Pada tuturan [22] [Guru] menunjukan wujud kesantunan diraktif nasihat yang berupa memperingatkan, dapat di lihat dari tuturan "Nah, contoh-contoh soal yang seperti ini harap kamu pahami betul. Perhatikan pertanyaannya, dipahami dulu baru memilih jawabannya." Tuturan tersebut memiliki makna seorang guru yang mengingatkan siswa-siswanya untuk lebih berhati-hati ketika menjawab soal-soal ujian agar tidak salah memilih jawaban. Dapat di lihat dari modalitas yang melekat yaitu adanya penggunaan kata harap sehingga tuturan [22] dapat dikategorikan ke dalam wujud direktif nasihat memperingatkan.

[25] G :'Semua halaman disebutkan tadi kamu baca yang harus kamu pelajari dan belajar itu dari sekarang bukan besok mau ulangan baru baca bukunya itu salah, dalam satu minggu ini ibu harap tidak ada lagi kegiatan yang tidak bermanfaat. Tiada hari tanpa belajar dalam minggu-minggu ini, kamu harus belajar tanpa membaca kamu tidak akan bisa menjawab soal, jadi Ibu harapkan kepada kalian supaya kamu benar-benar waktu digunakan dengan sebaik-baiknya jangan memikirkan ingin menyontek dengan teman. Sudah Ibu katakana walaupun dapat lima tapi hasil kerja kamu sendiri, kalau ulangan biasanya kaya itu. Jadi Ibu akhiri sampai di sini saja pelajarannya. Ingat kan pasan Ibu tadilah."

S : "Iya, Bu."

Konteks: (Dituturkan guru pada saat proses belajarmengajar berlangsung).

Pada tuturan [25] [Guru] menunjukan wujud kesantunan diraktif nasihat yang berupa menasihati, dapat di lihat dari tuturan [25] yang struktur kalimatnya memiliki makna menasihati siswa agar bisa memanfaatkan waktu belajar di rumah dengan sebaik-baiknya. Selain itu tuturan [25] tersebut ditandai dengan modalitas kata harap yang merupakan salah satu ciri dari wujud direktif nasihat. 


\section{B. Fungsi Kesantunan Direktif Guru Bahasa Indonesia dalam Proses Belajar-Mengajar di SMP Anggrek Banjarmasin}

Fungsi direktif dapat di bagikan menjadi beberapa kelompok diantaranya, (a) menyatakan fungsi perintah, (b) menyatakan fungsi larangan, (c) menyatakan fungsi persilaan, dan (d) menyatakan fungsi nasihat.

\section{Fungsi Direktif Perintah}

Dalam fungsi direktif perintah bisa juga di wujudkan dalam kelompok permintaan dengan modalitas yang melekat seperti, ayo, coba, tolong dan hendaklah.

[27] G : “Ini tolong dihapuskan!”(sambil menunjuk ke papan tulis).

S : ( salah satu siswa maju dan menghapus papan tulis)

Konteks: (Tuturan yang dihasilkan ketika guru meminta salah satu siswa yang berada di kelas untuk menghapus papan tulis).

Pada tuturan [27] [Guru] menyatakan sebuah fungsi direktif perintah, dapat di lihat dari tuturan [27] "Ini tolong dihapuskan!" tuturan tersebut memiliki fungsi memerintah dapat dilihat dari modalitas yang melekat pada tuturan [27] yaitu adanya penggunaan kata tolong, sehingga tuturan itu menghasilkan sebuah tindakan dari salah satu siswa yang berada di kelas.

\section{Fungsi Direktif Larangan}

Dalam menyatakan fungsi direktif larangan biasanya modalitas yang melekat pada tuturan adalah penggunaan kata jangan yang juga diikuti dengan partikel -lah.

$$
\begin{aligned}
\text { [33] S } & \text { : "Huuu...Huuuu....!" } \\
\text { G } & \text { :"Janganlah dibunyikan suaranya bersorak seperti } \\
& \text { itu, ini bukan sedang menonton pertandingan sepak } \\
& \text { bola, tapi kita ini sedang membahas contoh-contoh } \\
& \text { soal ujian." }
\end{aligned}
$$

Konteks: (Dituturkan oleh guru yang marah ketika mendengar siswanya bersorak nyaring ketika belajar di kelas).

Pada tuturan [33] [Guru] menyatakan sebuah fungsi direktif larangan, dapat di lihat dari tuturan [33] di atas tuturan tersebut memiliki fungsi melarang dapat dilihat dari modalitas yang melekat pada tuturan [33] yaitu adanya penggunaan kata jangan yang juga diikuti dengan partikel -lah, tuturan tersebut berfungsi melarang siswa yang mengeluarkan suara-suara bersorak nhyaring ketika belajar. Tuturan tersebut dihrapkan menghasilkan tindakan siswa agar menciptakan suasana belajar yang lebih tenang. 


\section{Fungsi Direktif Persilaan}

Dalam menyatakan fungsi direktif persilaan juga sejenis dengan melarang hanya saja, biasanya modalitas yang melekat pada tuturan adalah penggunaan kata silahkan, biarlah, diperkenankan, dan diizinkan.

\section{[35] G :"Silahkan di buka bukunya sekarang."}

Konteks: (Dituturkan oleh guru kepada siswa pada saat ingin memulai pelajaran).

Pada tuturan [35] [Guru] menyatakan sebuah fungsi direktif persilaan, dapat di lihat dari tuturan [35] di atas tuturan tersebut memiliki fungsi persilaan dapat dilihat dari modalitas yang melekat pada tuturan [35] yaitu adanya penggunaan kata silahkan tuturan tersebut berfungsi mempersilahkan semua siswa yang berada di kelas untuk segera membuka buku pelajaran karena pelajaran akan segera di mulai.

\section{Fungsi Direktif Nasihat}

Dalam menyatakan fungsi direktif nasihat juga sejenis dengan mengijinkan hanya saja, biasanya modalitas yang melekat pada tuturan adalah penggunaan kata mari, harap yang juga kadang-kadang ayo, coba, hendaknya, dan hendaklah.

[41] G :'Nak oh, sayang berapa kali sudah Ibu menegur. Sudah lupa dengan nasehat Ibu hari-hari yang lalu, bicara terus. Coba, ibu berharap sekali kamu ini bisa benar-benar belajar, karna ini semua juga untuk kebaikanmu."

Konteks: (Dituturkan oleh seorang guru kepada salah satu siswa yang terlihat tidak serius dalam mengikuti pelajaran).

Pada tuturan [41] [Guru] menyatakan sebuah fungsi direktif nasihat, di lihat dari tuturan [41] "Nak oh sayang berapa kali sudah Ibu menegur. Ini lupa sudah dengan pesanan Ibu nasehat Ibu hari-hari yang lalu, bicara terus. Coba, ibu berharap sekali kamu ini bisa benar-benar belajar, karna ini semua nantinya untuk kamu juga. "dalam tuturan [41] modalitas yang melekat pada tuturan yaitu adanya penggunaan kata coba dan berharap. Tuturan [41] berfungsi menasihati siswa yang kurang serius dalam mengikuti pelajaran di kelas.

\section{PENUTUP}

\section{A. Simpulan}

Dari hasil pembahasan, dapat disimpulkan pada tuturan guru Bahasa Indonesia dalam proses belajar-mengajar di SMP Anggrek Banjarmasin ditemukan wujud kesantunan direktif yang terbagi (a) permintaan (requestives), yang mencakup meminta, mengajak, memohon, mendorong, menekan; (b) pertanyaan (questions), yang mencakup bertanya, berinkuiri, menginterogasi; (c) 
persyaratan (requirements), yang mencakup menuntut, mengarahkan, mengatur, mengintruksikan; (d) larangan (prohibitions), yang mencakup melarang dan membatasi; (e) persilaan (permisives), yang mencakup pemberian izin, membolehkan, mengabulkan, memberi wewenag; (f) nasihat (advisories), yang mencakup menasihati, memperingatkan, menyarankan. Dalam hal ini, modalitas yang melekat dalam tuturan berbeda-beda disesuaikan dengan wujud tuturan yang dituturkan.

Selaian wujud direktif pada tuturan guru Bahasa Indonesia juga di temukan fungsi direktif diantaranya, (a) menyatakan fungsi perintah, (b) menyatakan fungsi larangan, (c) menyatakan fungsi persilaan, dan (d) menyatakan fungsi nasihat. Dalam fungsi direktif diharapkan adanya tindakan dari lawan tutur sebagai tolak ukur mencapai efektivitas tujuan dari fungsi tuturan yang situturkan.

Dari hasil penelitian yang telah dilakukan dilapangan dapat disimpulkan dengan diterapkannya prinsip kesantunan dalam proses belajar-mengajar khususnya dalam tindak tutur direktifnya, hal ini sedikit banyak akan menentukan hasil belajar siswa dan tentunya akan menimbulkan keharmonisan dalam berkomunikasi.

\section{B. Saran}

Sesuai dengan hasil dan keterbatasan penelitian ini, saran yang dapat dikemukakan adalah diharapkan penelitian ini dapat dijadikan sumber informasi bagi penelaah atau peneliti kesantunan di masa yang akan datang untuk menambah referensi dan sebagai bahan perbandingan. Kesantunan direktif guru Bahasa Indonesia dalam proses belajar-mengajar belum terungkap secara keseluruhan. Oleh karena itu, penelitian ini dapat dikembangkan dengan metode dan teori dasar lainnya.

\section{DAFTAR TUJUKAN}

Basrowi. Dan Suwandi. 2008. Memahami Penelitian Kualitatif. Jakarta: Rineka Cipta.

Chaer, Abdul. 2010. Kesantunan Berbahasa. Jakarta: Rineka Cipta.

Jumadi. 2005. Representasi Kekuasaan dalam Wacana Kelas. Jakarta: Pusat Bahasa, Departemen Pendidikan Nasional.

Jumadi. 2010. Wacana Kajian Kekuasaan Berdasarkan Ancangan Etnografi Komunikasi dan Pragmatik. Yogyakarta: Pustaka Prisma.

Kridalaksana, Harimurti. 2008.Kamus Lingusitik Edisi Keempat. Jakarta: PT. Gramedia Pustaka Utama.

Leech, Geofferey. The Principles of Pragmatics. Terjemahan oleh M.D.D. Oka. 1993. Prinsip-Prinsip Pragmatik. Jakarta: Universitas Indonesia.

Mahsun. 2005. Metode Penelitian Bahasa: Tahapan Srategi, Metode, dan tekniknya. Jakarta: PT. Rajagrafindo Persada. Edisi Revisi. 
Moleong, Lexy J. 2002. Metodogi Penelitian Kualitatif. Bandung: PT. Remaja Rosdakarya.

Nadar, F.X. 2009. Pragmatik dan Penelitian Pragmatik. Yogyakarta: Graha Ilmu.

Rafiek, Muhammad. 2007. Sosiologi Bahasa Pengantar Dasar Sosiolinguistik. Banjarmasin-Yogyakarta: FKIP PBSID Unlam dan PT. LKIS Pelangi Aksara.

Rahardi, Kunjana. 2003. Berkenalan dengan Ilmu Bahasa Pragmatik. Malang: Dioma.

Rahardi, Kunjana. 2008. Pragmatik Kesantunan Imperatif Bahasa Indonesia. Jakarta: Erlangga.

Rahardi, Kunjana. 2009. Sosiopragmatik. Jakarta: Erlangga.

Sardiman, A.M. 2011. Interaksi dan Motivasi Belajar Mengajar. Jakarta: RajaGrafindo.

Wijana, I Dewa Putu. \& Rohmadi, Muhammad. 2009.Analisis Wacana PragmatikKajian Teori dan Analisis. Surakarta: Yuma Pustaka.

Yule, George. Pragmatics. Terjemahan oleh Jumadi. 2006. Pragmatik. Banjarmasin: Unlam. 